\title{
NON-AGENDA
}

With the view of causing an increase to take place in the mass of national wealth, or with a view to increase of the means either of subsistence or enjoyment, without some special reason, the general rule is, that nothing ought to be done or attempted by government. The motto, or watchword of government, on these occasions, ought to be - Be quiet. . . Whatever measures, therefore, cannot be justified as exceptions to that rule, may be considered as non-agenda on the part of government.

\section{Power to the Artist: The False Promise of Moral Rights}

\section{Daniel Clode}

I

N March 1997, Australia's Commonwealth government announced the introduction of 'moral rights' into Australian copyright law. According to the Minister for the Arts and the Attorney General, Australian artists could now feel assured that 'the Government is empowering them' (Alston \& Williams, 1997).

'Moral rights' were first devised by French jurists as intellectual property rights for creators of artworks. These rights were conceived, not as economic in nature, but as protecting the spirituality and sentiments that artists encapsulate in their creations (Ricketson, 1987:456).

There are several categories of moral rights. The 'right of paternity' (also called the 'right of attribution') entitles artists to be known to the world as the creator of their works and to prevent others from falsely claiming authorship. The 'right of integrity' allows artists to sue anyone who modifies, distorts, or makes derogatory use of their creations. The 'right of disclosure' gives artists discretion over whether and when their work is to be divulged to the public. The 'right of withdrawal' allows artists to recall works from the public domain. The 'right of repentance' enables artists to modify, retract or disavow the messages originally expressed in their works. The 'right to prevent excessive critcism' conceivably gives mediocre artists plenty of opportunities to sue.

Daniel Clode is the political cartoonist for the Australian Medical Association and an Arts/Law undergraduate at The Australian National University. 
Moral rights are intended to remain with artists even after they have sold their artworks. Artists are thus to retain a say over how those artworks are displayed, labelled or published by future buyers.

However, it is argued here that moral rights legislation is unnecessary. In Australia, numerous legal remedies under common law, the Trade Practices Act and the Copyright Act are already available to artists who believe their moral rights have been violated by misuses of their artworks. Incomplete though this protection may be, there is another remedy which can be tailored to meet an artist's every concern and which prevents disputes in the first place. The greatest power artists possess lies in their freedom of contract, allowing them to forge terms of trade with their customers which resolve any anxieties about the paternity, integrity, publication or recall of their creative works. Moral rights legislation threatens to erode the level of coordination which such voluntary agreements can deliver.

Artists who are sensitive about alterations to their creations, or incomplete attribution, may insert appropriate conditions into their contracts of sale. Second and subsequent purchasers of an artwork may not be bound by such contracts, but the price paid by the first buyer can include a compensation premium. In this way, artists may insure themselves against affronts to their aesthetic tastes, while bearing the costs of these private preferences. By contrast, indiscriminate legislation forces such costs on to other artists who may not share those concerns.

\section{Approaches to Protecting Moral Rights}

There are three ways to protect moral rights. The opting-in approach allows artists to protect themselves primarily through contract, with the common law remedies of tort and equity as fallbacks. This system has operated in Australia for most of the 20 th century. The opting-out approach uses legislation with waiver provisions; this is the option proposed in the Copyright Amendment Bill 1997. The third approach, involving perpetual, inalienable and unassignable rights, is found in the French Code. These different approaches are set out in Table 1.

More than 60 countries currently employ the latter two approaches for giving legislative force to different combinations of moral rights (CLRC, 1988:32). The Australian Copyright Amendment Bill 1997 proposes to protect only the rights of attribution and integrity. 'Artists' who can lay claim to moral rights include painters, writers, poets, musicians, composers, movie directors and even producers. I therefore use the terms 'artist' and 'artwork' in this broad sense.

Australian advocates of moral rights legislation usually argue that Australia must honour its international obligations under the Berne Convention for the Protection of Literary and Artistic Works. In fact, signatories to this Convention are entitled to rely upon domestic legal traditions, such as defamation law. Countries may therefore employ significantly different approaches, and are not confined to copyright law (Ricketson, 1987:475). Indeed, Australia adopted this option when it became a convention signatory in 1928, by choosing to rely on existing common law remedies. 


\section{Table 1}

Approaches to protecting moral rights

\begin{tabular}{|c|c|c|c|c|}
\hline Moral right & $\begin{array}{l}\text { Concern to be } \\
\text { remedied }\end{array}$ & $\begin{array}{l}\text { Opting-in } \\
\text { (existing } \\
\text { remedies) }\end{array}$ & $\begin{array}{l}\text { Opting-out } \\
\text { (Copyright } \\
\text { Amendment } \\
\text { Bill 1997) }\end{array}$ & $\begin{array}{l}\text { Compulsion } \\
\text { (French law) }\end{array}$ \\
\hline $\begin{array}{l}\text { Paternityl } \\
\text { attribution }\end{array}$ & $\begin{array}{l}\text { False claim of } \\
\text { authorship or } \\
\text { failure to } \\
\text { acknowledge } \\
\text { actual creator. }\end{array}$ & $\begin{array}{l}\text { Passing off; } \\
\text { s.52 of Trade } \\
\text { Practices Act.; } \\
\text { defamation; } \\
\text { ss. } 190-192 \text { of } \\
\text { Copyright Act; } \\
\text { equitable } \\
\text { relief." }\end{array}$ & $\begin{array}{l}\text { ss.192-194; } \\
\text { 195AA-AG, } \\
\text { AN-AO, AQ. }\end{array}$ & $\begin{array}{l}\text { Originals, } \\
\text { copies and } \\
\text { quotes must } \\
\text { bear the name } \\
\text { or pseudonym } \\
\text { of the artist. }\end{array}$ \\
\hline Integrity & $\begin{array}{l}\text { Modification, } \\
\text { distortion, } \\
\text { parody or } \\
\text { derogatory use } \\
\text { of a creation. }\end{array}$ & $\begin{array}{l}\text { Passing off; } \\
\text { defamation; } \\
\text { ss.35(4)-(5) \& } \\
\text { ss.55(2) Copy- } \\
\text { right Act; equi- } \\
\text { table relief." }\end{array}$ & $\begin{array}{l}\text { Ss.195AH-AK, } \\
\text { AP, AR-AS }\end{array}$ & $\begin{array}{l}\text { Artist may sue } \\
\text { for any } \\
\text { change to } \\
\text { artwork or } \\
\text { setting, even if } \\
\text { not the owner. }\end{array}$ \\
\hline $\begin{array}{l}\text { Against } \\
\text { excessive } \\
\text { criticism }\end{array}$ & $\begin{array}{l}\text { Parody, } \\
\text { mockery or } \\
\text { severe criti- } \\
\text { cism. }\end{array}$ & $\begin{array}{l}\text { Defamation; } \\
\text { ss. } 41 \text { \& } 42 \text { of } \\
\text { Copyright Act; } \\
\text { equitable } \\
\text { relief." }\end{array}$ & & $\begin{array}{l}\text { Criticism of art } \\
\text { is actionable, } \\
\text { even if artist's } \\
\text { reputation is } \\
\text { not harmed. }\end{array}$ \\
\hline Disclosure & $\begin{array}{l}\text { Discretion to } \\
\text { determine when } \\
\text { and whether } \\
\text { work is divulged } \\
\text { to public. }\end{array}$ & $\begin{array}{l}\text { Detinue; con- } \\
\text { version; breach } \\
\text { of confidence; } \\
\text { restraint of } \\
\text { trade; defama- } \\
\text { tion; equitable } \\
\text { relief." }\end{array}$ & & $\begin{array}{l}\text { Artists can } \\
\text { refuse to } \\
\text { release art- } \\
\text { work, even } \\
\text { when contrary } \\
\text { to contractual } \\
\text { obligations. }\end{array}$ \\
\hline $\begin{array}{l}\text { Withdrawal/ } \\
\text { repentance }\end{array}$ & $\begin{array}{l}\text { Discretion to } \\
\text { withdraw work } \\
\text { from public; } \\
\text { modify, retract, } \\
\text { or disavow } \\
\text { messages in } \\
\text { artwork. }\end{array}$ & $\begin{array}{l}\text { Detinue; } \\
\text { conversion; } \\
\text { defamation; } \\
\text { equitable re- } \\
\text { lief." }\end{array}$ & & $\begin{array}{l}\text { Retraction or } \\
\text { modifications } \\
\text { allowed upon } \\
\text { change of } \\
\text { convictions. }\end{array}$ \\
\hline
\end{tabular}

${ }^{\star}$ E.g. unconscionability and estoppel.

\section{Inalienable Rights or Tradable Preferences?}

The Copyright Amendment Bill 1997 was promoted as a 'long overdue' protection of the most 'basic rights' for artists (Alston \& Williams, 1997). This rhetorical allusion to natural rights or divinely ordained entitlements was not reinforced by the legislative drafting. The Bill provided for the waiver of supposedly 'inalienable' rights to reputation as if these were economic choices that may be contracted away. This contradiction is the defining feature of the opting-out regimes that operate in 
leading common law countries, including the United Kingdom, Canada and the United States.

During a Senate Committee inquiry into the Copyright Amendment Bill 1997, industry bodies argued that they could not afford to operate without waivers, since artists might veto modifications to their works (SLCLC, 1997). Such vetoes would render useless many of the art stocks that advertising agencies have acquired over the years. Modifications could not proceed without compensation, consent forms, or court action. Against this, peak organisations of artists argued that if waivers were allowed under statute, then employers would write them into all standard contracts. They also argued against the waiver provision on the ground that waiver processes were 'economic' in nature (though they simultaneously sought economic forms of redress to compensate for alleged breaches of moral rights). But if moral rights exist to protect personal reputation and aesthetic concerns as opposed to economic interests, it is odd that they should endure for 50 years after an artist's death, concurrent with copyright. The estate of an artist cannot know with any certainty which uses of an artwork would have upset the artist, or when the artist would prefer to exercise a waiver of rights.

Without waivers, moral rights threaten art investors with major uncertainty, especially in the film and advertising industries where a chain of artists contribute to the final work. For example, many local films depend upon investment from the Australian Film Finance Corporation, which requires producers to obtain distribution contracts equivalent to 40 per cent of their budget. But broadcasters will usually not agree to buy distribution rights unless they can edit films to fit television time slots. If disputes over integrity rights deter broadcasters, many investors will not commit to new local production (Williams, 1997:219).

Yet even with waivers, moral rights impose major costs. Under such a system, arthouses, publishers, magazines and art syndicates need to implement internal monitoring systems and codes of conduct on the use of art, with all attendant expense. The paperwork burden can be massive, especially given the proposed retrospective application of moral rights to existing works (s.195AZL). Where an artist refuses to consent to changes to an artwork he has sold, the work must either be withdrawn or restored to its original condition.

The Australian bill allows for waiver of moral rights in the course of employment, prior to the creation of artworks (s.195AZG(3)). However, where artists work as contractors rather than employees, s.195AZG(2) limits waivers to specific works and may necessitate consent forms at every stage of production, including completion of advertisements and subsequent variations (AANA, 1997:465). These costs must ultimately impact on independent artists in the form of fewer work opportunities. The s.195AZG(3) mechanism for waivers over future works concedes that the pre-contractual negotiations are an appropriate point at which future uses of artwork can be anticipated. Why then restrict waivers to particular contractual situations, disadvantaging independent artists? Why not allow artists full freedom of contract, under which they can bargain terms covering the integrity and paternity of their art- 
works? The opting-in system thus generates fewer costs and distortions in the art industry than the opting-out model.

\section{Exploitation or Fair Bargains?}

In common law jurisdictions, the most compelling argument mounted for moral rights legislation draws upon notions from English equity law (Martin \& Bick, 1983:84-6). The argument is that struggling artists suffer from an inequality of bargaining power' which prevents them from negotiating fair terms under contract to govern the future uses and attribution of their work; only blanket legislation can ensure all artists against exploitation. This argument was the most prominent feature of community submissions to the Senate inquiry in support of moral rights.

Artists are said frequently to obtain bad deals because of a 'take it or leave it' approach by buyers. Yet, according to an AGB-McNair survey of 950 artists, of those artists engaged in contracts with galleries, agencies or managers, three times as many were satisfied with their contractual arrangements as were unsatisfied or uncertain (Throsby \& Thompson, 1994:79). When asked how they might improve their promotion, the most often cited method was 'more time/effort by artists themselves' (31 per cent). Only 11 per cent felt that a new agent was the solution (Throsby \& Thompson, 1994:38).

These statistics do not include sales outside an agent relationship. Perhaps only good artists get agents, fair deals and satisfactory incomes. However, 1991 census data on artistic professions provide little evidence of widespread exploitation (ABS, 1997:41). Among arts workers, 29.6 per cent earn $\$ 16,000$ or less, compared with 29.3 per cent in the total Australian workforce. True, 24.4 per cent earn between $\$ 16,001$ and $\$ 25,000$, significantly fewer than the 30.4 per cent in the general economy. But arts workers enjoy a greater share of high incomes than other professions: 46 per cent earn over $\$ 25,000$, compared with 40.2 per cent in the workforce as a whole. If gross incomes were adjusted to account for expenses incurred at work, the overall position of artists could be said to be only slightly worse than for the wider population. It should be noted that incomes do not reflect the job satisfaction and flexibility inherent in an artistic lifestyle.

The few cases of artists in poverty seem to have little to do with exploitation by art purchasers. A more salient cause may be found in the government subsidies which provide false flattery for sometimes undeserving artists and which entice some individuals into unsuitable careers on the very margins of economic survival. A significant 32 per cent of artists have applied for Australia Council grants in the last five years and 17 per cent have received grants at some stage in their career. Of those gaining grants, 21 per cent regarded their grants as a 'stimulus to continue' in the arts and 57 per cent felt the grants provided 'freedom from financial worries' (Throsby \& Thompson, 1994:97-8). These Australia Council figures indicate only a portion of dependence on grants since they do not measure how many have also sought or obtained funding from other Commonwealth agencies, States or local

\footnotetext{
${ }^{1}$ The median level of arts-related expenses is $\$ 3,500$ (Throsby \& Thompson, 1994:26).
} 
governments. The levels of dependency exposed in these 1993 survey findings are consistent with a 1988 survey which found that 39 per cent of artists believed that 'buying time' was the most important purpose of grants, while only 9 per cent viewed grants as a vehicle for 'experimentation and innovation' (Throsby \& Thompson, 1994:49).

According to Browning (1995:162), over 60 per cent of the books subsidised by the Australia Council's Literature Board sold no more than half their print run. It is little wonder that some incomes in the arts are particularly low, when governments are encouraging unmarketable talent into professional practice. These policies have contributed to a chronic labour oversupply, leaving only 24 per cent of all artists with regular income, 20 per cent on semi-regular income and 51 per cent on intermittent income (Throsby \& Thompson, 1994:73). The oversupply of labour, rather than power imbalances and unfair deals, appears to be the biggest cause of any income depression in the arts.

\section{Legal Attrition or Market Sanctions?}

The market provides artists whose works have been abused with a less costly tool of retribution than court remedies, which can be both expensive and uncertain in outcome. Buyers who abuse artworks will acquire a negative reputation and lose the best artists. We might describe this as the 'sanction of opprobrium'. The impact of reputational losses are asymmetric (Epstein, 1984:967), to the advantage of artists. For instance, the ratio of painters to galleries makes it easier for the former to monitor the latter than vice versa. If bargaining power is at all unequal in the arts, it may not be the buyer who has the upper hand.

A moral rights regime creates incentives for artists to seek legal 'recovery' to heal wounded egos. Lesser-known artisans have the greatest incentive to instigate moral rights actions, whereas able artists can find alternative employment to mitigate the loss of any soured trading relationship. The ironic danger is of an erosion of the creative spirit by the destructive emotions that come with litigation.

Under moral rights law, court action could be mounted over petty 'rights' breaches which might not otherwise provoke the opprobrium of the market. This is apparent from records of international negotiations over mutual copyright law recognition. Court action is intended to be available over 'a literary work ... published in conjunction with numerous advertisements; an artistic work reproduced in conjunction with articles not enjoying a good reputation; a musical composition, profoundly serious and religious in tone, adopted as part of a filmed operetta' (Ricketson, 1990:473). Submissions to the CLRC argued that lawsuits should be available to prevent inadequate lighting of art; placement of furniture in front of art; and failure to hang commissioned work (CLRC, 1988:14). In such cases, the incentive to reap a court award of money might be sufficiently strong to overwhelm the normal instinct to keep a trading relationship going.

The notion of 'moral' rights imputes base motives to those who may inadvertently offend the sensitivities of artists. Similarly, the pejorative concept of 'unfair' dismissals has been used unjustly to stigmatise many employers. The moral offen- 
siveness of an investor's conduct is most accurately measured when aggrieved artists signal opprobrium by ending a commercial relationship.

Artists have the opportunity to protect their concerns by specifying in contracts how their artworks may be used. Buyers who break agreements on layout or acknowledgments will not only lose the best artists, but will also be liable for contractual damages. Artists in some fields have been very diligent in utilising standardform contracts over many years to protect themselves against problems of paternity and integrity (Martin \& Bick, 1983:80-3). Greater use of standard contracts by art vendors would not only assist in insuring against unforeseen problems, but could also increase the availability of promissory estoppel remedies in situations involving established trading partners who operate without a formal contract.

\section{Protectionism or Cultural Renewal?}

In theory, moral rights legislation protects creativity as if it were a form of capital invested by artists. But in what way is the artist's creativity special? Why should not the landscape gardener claim the same legal privileges as the graphic designer? If a painter is to be compensated if one of his canvasses is touched up by a buyer, why should the house builder who is upset to see an old specimen of his craftsmanship renovated not likewise be compensated?

Even supporters of moral rights have become entangled in contradictory arguments over which professionals should claim authorship. The most heated dispute is over cinematographic works (SLCLC, 1997). Film and television often involves dozens of writers and directors, any one of whom could frighten away investors if they used their moral rights to veto script changes. In Australia's draft legislation, producers and directors were defined as authors, while scriptwriters were left out. The predictable debate that ensued over which vocation is the true source of creative genius served to expose the danger of moral rights in an industry which is essentially a collaborative venture.

The pioneers of moral rights jurisprudence were driven by juristic notions that law should strengthen over time (Stromholm, 1983:6). Indeed, the majority of submissions to the Senate inquiry into moral rights called for more extensive protection than was originally proposed (SLCLC, 1997). Despite deliberate loopholes in the draft legislation allowing 'reasonable' infringements of integrity rights (s.195AR), parodies of artworks can still fall foul of a moral rights regime. A 'reasonableness' criterion may actually encourage litigation, precisely because of the indeterminate nature of the concept (CLRC, 1988:18).

Artists are wonderfully equipped to lampoon new fashions in the arts. In the past, artistic ridicule could be requited in kind. But under moral rights legislation, the lawyer can annex the satirist's drawing board. Moral rights supporters argue that parodies can be tested for harm to the author's honour or reputation (Wier, 1992:196). But real harm to reputation is already actionable under current defamation law. If an especially vicious attack destroys an artist's following, then remedies exist allowing the recovery of economic damages. By contrast, if the artist's clientele remains loyal after an attack and that attack did not constitute defamation, then no 
substantial damage has been inflicted that might justify legal action. Under copyright law, the partial replication of an original artwork is permissible in a parody, provided the secondary work does not confuse the buyers by stealing the market for the original. To quote the courts: 'Biting criticism suppresses demand; copyright infringement usurps it'.

The submission by a major law firm to the recent Senate inquiry illustrated the dangers of moral rights with examples from two French court cases:

A vibrant culture will look critically and carefully at its values and priorities. One of the more effective methods is to reassess and reinterpret its cultural heritage.

Moral rights may inadvertently stymie this cultural development ... Gustav Holst was able to restrain a modern reinterpretation of the electronic version of his composition 'The Planets'. Analogously, Beethoven's estate could have stopped Lizst's arrangements of Beethoven's work. Similarly, the Beckett estate's action to restrain Beckett's 'everyman' play 'Waiting for Godot' with a female cast robs the modern audience of an interesting reinterpretation, and firmly roots the work in a different era where the only relevant audience was 'everyman'. (Williams, 1997:227)

\section{The Costs of Corporatism}

Australian studies have chronicled few cases where moral rights were seriously abused. By 1983, there had been only one published list of known breaches, totalling 14 cases. Some of these incidents revealed 'over-sensitivity' and 'unreasonableness' by the artists involved (CLRC, 1988:26). In 1992, the Australian Copyright Council received 10,472 copyright enquiries, of which only 77 related to moral rights. Visual artists and writers made more queries than did authors of musical works or films. The main interest of visual artists was potential misuse of original works, not reproductions (Department of Attorney General, 1994:22). However, I am aware of no empirical study that catalogues the number of serious incidents each year or details whether power imbalances existed, which other legal remedies were available, and what evidential difficulties existed.

Supporters of moral rights legislation recognise that if the French laws were ever fully enforced, the community would find them 'burdensome and unworkable' (Department of the Attorney-General, 1994:31). Such laws which are tolerable only in a state of non-enforcement are probably not worth keeping. Laws which threaten to do the greatest harm to those whom they purport to assist are not even worth acquiring. The strengths of a free market should not be judged by the drama of the few abuses, but by the multitude of successes where trading partners are cemented together by goodwill. Legislative attempts to anticipate the few possible failures involve attaching to every contract obligations designed to cover all imaginable contin- 
gencies. Thus, contracts which were intended by their authors to be simple and flexible become complex and uncertain in their effect.

The costs of moral rights go well beyond court expenses. Industry compliance will necessitate consent forms and compensation to cover thousands of existing artworks. Given that the total annual income of all artists (including proceeds from the sale of artworks) was $\$ 1.2$ billion at the 1991 census (ABS, 1997:44), the possible cost of introducing a moral rights regime could total at least millions of dollars. Even more ominously, any attempt by future Commonwealth governments to transfer moral rights within collaborative ventures (such as the film industry or the information technology sector) could require payment of 'just terms' compensation to previous moral rights holders under s.51(xxxi) of the Constitution. Unless moral rights are legislatively defined as tort actions rather than as property rights, it becomes prohibitively expensive to alter their scope, even though in future there may be pressing economic, technological or cultural reasons to do so.

Ever since the Gorton Government of 1968-71, federal politicians have viewed the Australian arts community as an articulate adoptee, politically appreciative of favours. Recently, as swelling public debt has limited the scope for financial largesse, regulatory favouritism has become the new currency of corporatism. Yet strength never comes to those who sit at the table of 'infant industries' singing for a supper of subsidies and regulatory benefits. Legislation which advantages my craft only strengthens the claims of those in other realms of productive endeavour who demand an offset for my privileges. True power comes only with independence. A wise artist would say to the Arts Minister, 'Please sir, may I go without?'

\section{References}

Alston, R. \& D. Williams (1997), Media Release, 4 March.

Australian Association of National Advertisers (AANA), (1997), Submission 8 August, pp. 461-66 in SLCLC, Submissions: Copyright Amendment Bill 1997, Vol. 2, Canberra.

Australian Bureau of Statistics (ABS) (1997), Artswork: A Report on Australians Working in the Arts, Australia Council, Sydney.

Browning, B. (1995), Bad Govemment, Canonbury Press, Melbourne.

Copyright Law Review Committee (CLRC) (1988), Report on Moral Rights, AGPS, Canberra.

Department of the Attomey-General (1994), Proposed Moral Rights Legislation for Copynight Creators: Discussion Paper, Office of Legal Information and Publishing, Canberra.

Epstein, R. (1984), 'In Defense of the Contract at Will', University of Chicago Law Review 51: 947-82.

Martin, S. \& P. Bick (1983), Moral Rights for Artists, Australia Council, Sydney.

Ricketson, S. (1987), The Berne Convention for the Protection of Literary and Artistic Works, 18861986, Eastern Press, London.

${ }^{3}$ Smith Kline \& French v Secretary Department of Health (1990) 95 ALR 87. 


\section{Non-Agenda}

- (1990), 'Is Australia in Breach of its International Obligations with Respect to the Protection of Moral Rights?', Melboume University Law Review 17: 462.83.

Senate Legal and Constitutional Legislation Committee (SLCLC) (1997), Submissions: Copyright Amendment Bill 1997, Vols 1-3, Canberra.

Stromholm, S. (1983), 'Droit Moral - The International and Comparative Scene from a Scandinavian Viewpoint', International Revicw of Industrial Property and Copyright Law 14: 1-42.

Throsby, D. \& B. Thompson (1994), But what do you do for a livings: a new economic study of Australian artists, Australia Council, Redfern, NSW.

Wier, M. (1992), 'Making Sense of Copyright Law Relating to Parody: A Moral Rights Perspective', Monash University Law Review 18: 194-206.

Williams, D. (1997), Mallesons Stephen Jaques Submission 8 August, pp. 214-28 in SICLC, Submissions: Copynight Amendment Bill 1997, Vol. 1, Canberra. 